\title{
The Periphery is the Centre: Some Macedonian Origins of Social Medicine and Internationalism
}

\author{
Sara Silverstein ${ }^{*}$ \\ History Department and Human Rights Institute, University of Connecticut, 241 Glenbrook Road, Wood Hall U-4103, \\ Storrs CT 06269, USA \\ *sara.silverstein@uconn.edu
}

\begin{abstract}
A new and important model for international health originated in the 1920s as a rural health project in the Macedonian region of Yugoslavia. Thus, the involvement of international organisations in social stability and human security did not follow the Great Depression of the 1930s, as has been argued. In fact, the redefinition of the League of Nations' mandate began with its Health Organisation in the 1920s, growing from local health projects. These initiatives adapted principles of social medicine to address the challenges of constructing egalitarian democratic states in the agrarian peripheries of post-imperial Europe.
\end{abstract}

While in the past, and partly even to-day, the successes of, and benefits from, practical sciences were and are enjoyed only by the rich, the present age aims at making science and its practical applications a common possession of all members of society.

$\sim$ Andrija Štampar, $1911^{1}$

In 1938 the Yugoslav physician and public health expert Andrija Štampar (1888-1958) toured the United States. His American colleagues were eager to show off their progress in medicine and healthcare. Štampar, however, was unimpressed. He compared their initiatives unfavourably with European methods which integrated questions of health and disease with the social environment. The United States, he opined, was too focused on private medicine, and its doctors failed to appreciate the socio-economic determinants of health. Crossing the country, he listened to controversies over social policy. He noted that doctors often did not receive the training to study and interpret social contexts, and he also recorded the lack of diversity among students in medical schools. He remarked upon the obvious inequality in living standards, and was shocked by racial divisions that often underlay those standards. He saw as a whole the politics, the education and the conditions of daily life that shaped healthcare in the United States. Along the way he shared his opinions about the state of US healthcare with his hosts, who expressed chagrin in the face of Štampar's vociferous judgements. Štampar decided that New Deal policies were just beginning to make Americans better understand 'social issues and responsibilities'.

\footnotetext{
1 Andrija Štampar, 'Socijalna Medicina', in Štampar, U Borbi za Narodno Zdravlje: Izabrani Članci Andrije Štampara, ed. Mirko Dražen Grmek, (Zagreb: Škola narodnog zdravlja, 1966), 51. Translation: Andrija Štampar, 'Social Medicine', in Štampar, Serving the Cause of Public Health: Selected Papers of Andrija Štampar, ed. Mirko Dražen Grmek, trans. M. Halar (Zagreb: Škola narodnog zdravlja, 1966), 53. Originally published in Zora, 3 (1911).

2 Quote: Andrija Štampar, 5-11 Mar. 1938, in Željko Dugac and Marko Pećina, eds., Dnevnik s putovanja 1931-1938 (Zagreb: Srednja Europa, 2008). On Štampar's travels, see Dugac and Pećina, Dnevnik, Feb.-May 1938; Memorandum of Alan Gregg's interview with D. Štampar, 24 May 1938, Rockefeller Foundation Archives (hereafter: RF), 1.1/710/3/18; Štampar to O’Brien, 26 Apr. 1938, RF, 1.1/710/3/18.
} 
Štampar was observing - and judging - a divergence within modern medicine that had occurred in the first part of the twentieth century. In contrast to the United States, influential Eastern European healthcare experts focused on redefining the meaning of, and means for achieving, health within society. In particular, they responded to the specific needs arising from agrarian conditions and national politics in the states established after the First World War. The debates over different approaches to healthcare quickly expanded beyond local considerations. In the two decades that preceded Štampar's visit to the United States a model of healthcare that took into account socio-economic circumstances competed with its US counterpart to establish standards and operational methods for international health programmes. By the time Štampar made his tour in 1938 the rural health programme he had pioneered in Yugoslavia had contributed to making agrarian focused social medicine a significant element in the origin of international development. In the context of this international programme Štampar's colleagues challenged the very idea that modern medicine could succeed without understanding social factors in health and disease.

Štampar's logic, more radical than that of many, suggested that social medicine implied socialised medicine that empowered the people. In the United States, and often in Western Europe, 'public health' referred to sanitation, hygiene and control of infectious disease. For a circle of reformers further east, 'public health' merged with 'social medicine' and meant dispersing health services to each individual within the population. It meant making healthcare a service provided by the state. It also represented an instance of pragmatically utilising social science in a moment of state construction. ${ }^{3}$ Andrija Štampar was a young physician of thirty-one when he became the first director of public health in the Kingdom of Serbs, Croats and Slovenes in 1919. In this position Štampar pursued nothing less than a universal health service. As he explained when he toured the United States, he trained his staff of public health workers to treat medicine as a field of applied sociology. They would thereby acquire, he believed, an understanding of society that would form the basis for establishing egalitarian access to health services. ${ }^{4}$ Health was not only an absence of disease achievable by a uniform method of targeted scientific intervention, as the US system favoured. Rather, health was the thriving of individuals within their specific society. Understood as such, social medicine, Štampar explained, was a new science, akin to sociology and distinct from similar existing branches of medicine. Those existing practices, which failed to fully comprehend social context or that forced artificial control over that context, he identified as social hygiene. ${ }^{5}$

The dark history of eugenics has produced a tendency to conflate understandings of social medicine in interwar Europe with eugenics. This leads, for example, to assumptions about the nature of social medicine's concern with the nation. A closer understanding of Štampar's work reveals that social medicine was both a broader field and was engaged with state building in more nuanced ways. The creation of new states in Eastern Europe after the First World War out of the remnants of the Habsburg, Russian and Ottoman empires introduced a moment for envisioning and building state services from the foundation. Under these circumstances reformers like Andrija Štampar took action, anticipating that their ideas of healthcare might assume weight in the political sphere. Public health reformers took the opportunity to extend government

\footnotetext{
3 Patrick Zylberman's intellectual history of differences between social medicine in Eastern and Western Europe shows the latter focused on the family, while the former was concerned with rural health and the village. Zylberman also points to the influence that the Eastern European approach had on the League Health Organisation. My article will examine how these theories operated in practice and their channels for influencing international institutions. Patrick Zylberman, 'Fewer Parallels than Antitheses: René Sand and Andrija Stampar on Social Medicine, 1919-1955', Social History of Medicine, 17, 1 (2004).

4 'Health Purchasable if you Have Price', Kern Herald, 22 Apr. 1938, s.n.; 'League of Nations Health Leader Honored at Dinner', RF, 1.1/710/3/18.

5 Andrija Štampar, O Socijalnoj Medicini (Belgrade: Štamparija Drag. Gregorića, 1923), 2, League of Nations Health Organisation Archives (hereafter LNHO), R.853/12B/26249/27295X. The terms in Croatian are 'socijalna medicina', 'socijalna higijena', 'socijologijom'.
} 
responsibility for health services, resulting in greater government involvement in healthcare than existed to the west. ${ }^{6}$

On the one hand, this closer involvement was associated with implementing eugenicist theory in the name of state building: moulding and disciplining the biological nation into a physically stronger, and in its more radical version a purer, form. ${ }^{7}$ The field of eugenics was part of social medicine and public health during the first half of the twentieth century. Its malignant legacy, however, should not overshadow the entire history of social medicine.

On the other hand, Štampar's programme was one example of a different relationship between health and citizenship. This programme aspired to enact a virtuous circle, health reinforcing democracy, democracy reinforcing health. The methods for achieving these ends were not necessarily flawless. Štampar and colleagues exhibited all the paternalism of experts interested in reshaping society. ${ }^{8}$ His concern was with socio-economic development and with the health of the individual as a component of a healthy state - all issues that engaged eugenic thought as well. Nor did Štampar, any more than his colleagues, clearly eschew eugenicist ideas. ${ }^{9}$ Nevertheless, his programme cannot be reduced to eugenic practices. The nature of power and politics that emerged in rural Yugoslavia, exemplified by Štampar's programme, was more interesting. His project decentralised ethnic for civic nationhood, assimilation for integration and the population's discipline for transparent governance and the government's responsiveness to its citizens.

The malleability of new states created a setting in which Štampar reimagined the terms of public health, establishing healthcare based on his sociological principles as an active - and even a determining - factor in rural politics. Public health under Štampar would become a means of introducing powers of choice and agency to peasant populations in an emergent agrarian democracy. He acted on the principle that policy and institutions served the people, and that the people had a basic right to access medical services. To achieve this objective he had to address the common challenges of healthcare planning in rural Eastern Europe, where poor roads alone might limit access to equal care and where insurance did not extend to agricultural labour. ${ }^{10}$ An integrated approach to healthcare seemed to offer a fundamental step toward socio-economic and political development.

Understanding Štampar's idea of social medicine rooted in rural health illuminates the path by which interwar internationalists became engaged with social issues. The ideas of rural health that emerged in this post-imperial environment entered international consciousness and prompted international cooperation through the League of Nations Health Organisation, which operated

\footnotetext{
${ }^{6}$ Marius Turda, The History of East-Central European Eugenics, 1900-1945 (London: Bloomsburg, 2015), xi-xxii. See also Christian Promitzer, Sevasti Trubetaand Marius Turda, 'Framing Issues', in Promitzer et al, Health Hygiene and Eugenics in Southeastern Europe to 1945 (Budapest: Central European University, 2011); Keely Stauter-Halsted, The Devil's Chain: Prostitution and Social Control in Partitioned Poland (Ithaca, NY: Cornell University Press, 2015), 7-8, 343.

7 On eugenics in Eastern Europe, see Marius Turda and Paul Weindling, eds., 'Blood and Homeland': Eugenics and Racial Nationalism in Central and Southeast Europe, 1900-1940 (Budapest and New York: Central European University Press, 2007); Turda, East-Central European Eugenics; Promitzer et al. Health Hygiene. See also the argument that 'biological determinism' never became official policy in southeastern Europe, while the idea of a 'Yugoslav race' altered eugenic theory from that found elsewhere: Promitzer et al. 'Framing Issues', Health Hygiene, 16, 19.

8 On Štampar's approach, see Lewis Hackett to Selskar Gunn, 25 Mar. 1925, RF, 1.1/710/2/11; Selskar Gunn, 'Public Health in Jugoslavia', 1924, 56, RF 6.1/1.3/46/524 (hereafter: Gunn, 1924 Report); W. Leland Mitchell, 'Trip to Jugoslavia', 21 Nov.-1 Dec., 1927, 3, RF 1.1/710/2/10 (hereafter: Mitchell, 1927 Report).

9 On Štampar and eugenics: Marin Kuhar argues Štampar moved away from an early interest in eugenics in Marin Kuhar, "'From an Impure Source, All is Impure": The Rise and Fall of Andrija Štampar's Public Health Eugenics in Yugoslavia', Social History of Medicine, 30, 1 (2016), 1-22; Vjera Duić, 'Yugoslavia II. Croatia', in Marius Turda, ed., The History of East-Central European Eugenics, 1900-1945 (London: Bloomsbury, 2015), 438, also 422-6, 437-9.

10 On rural health, insurance and free services, see Andrija Štampar, 'Organisation of the Public Health Services in the Kingdom of the Serbs, Croats and Slovenes', 1925, LNHO, C.H.326; Hermann Schroetter, 'Public Health Services in Austria', 1923, LNHO C.825.M.314/C.H.141; Alexander de Dobrovits and Aladár de Fáy, 'Public Health Services in Hungary', 1925, LNHO, C.H.265; Hynek J. Pelc, 'Organisation of the Public Health Services in Czechoslovakia', 1924, LNHO, C.H.268; 'European Conference on Rural Hygiene, June 29 to July 7, 1931', s.n., vol. II (Geneva: League of Nations, 1931), C.473.M.202.1931.III(vol.ii), 38.
} 
under the direction of the Polish physician Ludwik Rajchman (1881-1965). Encouraged by Rajchman, experts came together on an international level to address the vulnerabilities of agrarian society. Historical discussions typically begin by looking at the Great Depression of the 1930s to identify the motivating factor driving international concern in social issues. In the 1930s the Great Depression aggravated an agrarian crisis that threatened global food security. This precarious situation generated interest in an international approach to stabilising and modernising rural economies. ${ }^{11}$ However, by the mid 1920s transnational collaboration around rural health had already created an entrance for the international health organisation into these questions. New concern in the 1930s extended their resources and their acknowledged mandate but built on existing methods and projects.

Štampar's social medicine, or medical sociology, focused on the challenges of agrarian society within the newly democratic, modernising state. In the process of building institutions to achieve these objectives his programme confronted the way states thought about citizenship, democracy and modernisation. For Štampar, universalising healthcare was an implicit method and objective of social medicine, and in Eastern Europe the issue inherently started with rural health. Principles of access to services within Yugoslavia could overflow into more general universal principles, thanks to the institutional structure of the rapidly growing League Health Organisation.

\section{The Place of Public Health in a New State}

Andrija Štampar assumed the position of director of public health in the Kingdom of Serbs, Croats and Slovenes in 1919. At the time the health administration and resources available to it were inequitably distributed across the country's disparate regions. The Kingdom of Serbs, Croats and Slovenes (hereafter Yugoslavia) was formed in 1918 from at least eight regions, distinct in their cultural, political, legislative and administrative legacies. Štampar was himself a product of these legacies. He was born to Croatian parents in a village governed by the Hungarian half of the Habsburg Empire. He studied medicine in Vienna because Habsburg authorities refused to build a medical school in the Balkans. Instead they brought provincial students to the metropole to make them part of the centralised imperial health administration. ${ }^{12}$ Stampar began his career by observing that his training failed to take into account the specific social factors affecting health in the Balkans. ${ }^{13}$ In 1919 Štampar joined a government that seemed in certain ways to echo the imperial structure and problems of the recently dissolved state. Opponents of the Yugoslav government accused Serbia of dominating the new country. Officials in Belgrade despaired of extending their governance across the country. The citizenry consisted largely of peasants, many of whom were suspicious of Belgrade. Indeed, some regions were so remote that the distant government hardly seemed likely to play a part in local life. ${ }^{14}$

The geographic, political and social composition of the new state posed challenges for Štampar, but he found encouragement in the apparent value the government placed on healthcare. The Yugoslav constitution of 1921 would include an article acknowledging responsibility for the health of its people, as was common among the new European states. ${ }^{15}$ However,

11 Sunil Amrith and Patricia Clavin, 'Feeding the World: Connecting Europe and Asia, 1930-1945', Past \& Present, 218, 8 (2013), 29; Iris Borowy, Coming to Terms with World Health (Frankfurt: Peter Lang, 2009), 361-4; Paul Weindling, 'Social Medicine at the League of Nations Health Organisation and the International Labour Office Compared', in Weindling, ed., International Health Organisations and Movements, 1918-1939 (Cambridge: Cambridge University Press, 1995), 143-7.

12 Mirko Dražen Grmek, 'Introduction', in Štampar, Serving the Cause, 15-6.

13 Andrija Štampar, Public Health in Jugoslavia (London: UCL School of Slavonic and East European Studies, 1938),3; Grmek, 'Introduction', 18-20.

14 Gunn, 1924 Report, 237; Mitchell, 1927 Report, 30-1; Andrija Štampar speaking in Minutes of Third Meeting, 22 Apr. 1926, Teaching of Hygiene: Proceedings of Fourth Session of Committee at Warsaw, LNHO, R.861/12B/26435/51114X.

15 The Constitution of the Kingdom of Serbs, Croats and Slovenes, 28 June 1921 (St. Vitus's Day Constitution), Arhiv Jugoslavije: http://www.arhivyu.gov.rs/active/en/home/glavna_navigacija/leksikon_jugoslavije/konstitutivni_akti_jugoslavije/ vidovdanski_ustav.html (last visited 12 Sept. 2016); regarding article on health, see Gunn, 1924 Report, 29. 
putting this plan into practice proved more difficult, particularly because of the country's regional inequalities. The Ministry of Health had only ten centres of operation in Yugoslavia in 1922, and three of these centres were concentrated in Serbia, leaving other regions without any. ${ }^{16}$ The ideal was for each township to have a health officer who would report to one of the centres, but in practice it was not yet possible to provide state sponsored localised care. Each township had to pay for its own health officer if it wanted and could afford one. ${ }^{17}$ These health officers performed only basic public hygiene and sanitary inspector services, and they were disinclined to give up private practice for employment in a free state managed health service. ${ }^{18}$

In 1924 Štampar overhauled the Department of Public Health, taking advantage of disorganisation in the government to secure single-handed authority over his administration. ${ }^{19}$ His purpose was to build a health service that would reach every citizen of Yugoslavia. He opened clinics across the country, consciously trying to ensure that all regions benefited. However, lacking the resources to establish a full health service across the country simultaneously, he concentrated the project in the region known as Macedonia. ${ }^{20}$ He planned to expand from there, three years later making arrangements to extend the programme into Bosnia. By Štampar's estimate it would take thirty to forty years to build a comprehensive public health service throughout the country. ${ }^{21}$

Štampar's method for expanding the programme required gradual growth, depending on village level organisation. He favoured centralised administrative control in the beginning but quickly learned to devolve control and financial responsibility away from Belgrade. ${ }^{22}$ Besides avoiding the changeable political currents in the capital, Stampar sought - and himself came to rely increasingly on - the cooperation of the people he wished to reach. Individual and communal agency became the foundation for his work in Macedonia.

\section{Health and Citizenship}

Both health concerns and the political situation prompted Štampar's decision to begin in Macedonia. The region remained the most politically unsettled part of Yugoslavia and was further isolated within the new state by poor infrastructure and linguistic differences. ${ }^{23}$ The government addressed this situation by perpetuating the system of colonial rule that Serbia had previously implemented and by suppressing the Macedonian nationality. Štampar used his position in the Ministry of Health to establish a new approach. The conventional application of colonial public health in the region would have targeted diseases that made the climate inhospitable for colonial settlers and economic exploitation. ${ }^{24}$ Instead, Štampar advised 'thorough study of the peasants, their life, their psychology and their needs'. ${ }^{25}$ He shared his government's interest in erasing the significance of national identity but by superseding national with civic identities that empowered the people in their relationship with the government.

16 Gunn, 1924 Report, 33.

17 Ibid., 34.

18 Selskar Gunn, 'Notes on a Visit to Jugoslavia', 3-8 Feb. 1926, RF, 1.1/710/2/11 (hereafter: Gunn, 1926 Report); W. Leland Mitchell, Report on the Public Health Situation in Southern Yugoslavia (Macedonia), Sept. 1926, 78, RF 6.1/1.3/48/539 (hereafter: Mitchell, 1926 Report), 93-4.

19 Gunn, 1924 Report, 29-33; Hackett to Gunn, 25 Mar. 1925, RF, 1.1/710/2/11.

20 Letter from Štampar to Ludwik Rajchman, 16 Nov. 1926, LNHO, R.991/12B/55556X/55556; Gunn, 1924 Report, 54.

21 Mitchell, 1926 Report, 80; Gunn, 1924 Report, 238.

22 Gunn, 1924 Report, 56; Gunn to Frederick Russell, 23 Dec. 1925; Gunn, 1926 Report.

${ }^{23}$ Gunn, 1924 Report, 6; on language, see Keith Brown, The Past in Question: Modern Macedonia and the Uncertainties of Nation (Princeton: Princeton University Press, 2003), 42.

24 See Patrick Zylberman, 'Mosquitos and Komitadjis: Malaria and Borders in Macedonia (1919-1938)', in Iris Borowy and Wolf D. Gruner, eds., Facing Illness in Troubled Times: Health in Europe in the Interwar Years, 1918-1939 (Frankfurt am Main: Peter Lang, 2005).

25 Štampar to Alice Masaryková, 1 Mar. 1933, Hrvatski Državni Archiv (Croatian State Archive, hereafter: HDA), 831.5. 
The region was known for poor health, and especially for malaria. Yugoslavia had one of the highest rates of malaria in Europe and the entire Macedonian region in particular was badly affected. $^{26}$ Stabilising the region politically and making it economically viable would require controlling malaria. Health officials at the time, including Štampar, considered even banditry 'a symptom of malaria'. ${ }^{27}$ This colourful description referred to the disease's seasonal interference with the cycle of planting and harvest, consequently depressing economic development. ${ }^{28}$

Politically, Macedonia was one of the most fraught regions in Europe. The problems of nationality and contested territorial possessions in the south-central Balkans found expression as a 'Macedonia Question' in the nineteenth century. This provocative and potentially unresolvable formulation did not find a solution in the creation of a new Yugoslav state. The Macedonian nationality itself had emerged as an unplanned consequence of competing Greek, Bulgarian and Serbian nationalisation projects in the region during the last third of the nineteenth century. ${ }^{29}$ These national contests produced a legacy of violence, including a brutal uprising in 1903 and an active front in the region both during the Balkan Wars and the First World War.

Lack of official recognition further radicalised elements of Macedonian society. Through treaties following the Balkan Wars and the First World War, 50 per cent of the contested region went to Greece, 40 per cent to Yugoslavia and 10 per cent to Bulgaria. ${ }^{30}$ Macedonian representatives appealed to the Paris Peace Conference in 1919 first for their own independent state and later for recognition as a minority nationality under the Minority Treaties that the Conference obligated the new states to sign. The Macedonian delegation received no hearing in Paris. ${ }^{31}$ Yugoslavia treated the Macedonian question as 'non-existent'. It argued against minority status on the grounds that the Macedonian identity was a Bulgarian construction that Bulgaria would use as a tool against Yugoslavia. Under the League's Minority Treaties minority status was awarded only to groups that were loyal to their governing state. ${ }^{32}$ Yugoslavia, denying the existence of a Macedonian nationality, erased the name from the region, calling it South Serbia or the Vardar. The government made a further attempt to dissolve regional identity by dividing and redividing the country in 1922 and 1929 into new counties and provinces that disregarded identities associated with previous borders. ${ }^{33}$

Despite its unrest the remote region was a microcosm of the multinational, agrarian, postimperial identity that characterised Eastern Europe. Self-identified Macedonians shared the land

26 It was estimated that one million people, or a twelfth of the Yugoslav population, suffered from malaria. Gunn, 1924 Report, 116.

27 Ibid., 10.

28 Ibid. Disease was commonly regarded as a factor limiting economic development in the Balkans. See John R. Lampe and Marvin R. Jackson, Balkan Economic History, 1550-1950: From Imperial Borderlands to Developing Nations (Bloomington: Indiana University Press, 1982), 1.

29 On the history of Macedonian nationality, see Brown, Past in Question; Anastasia N. Karakasidou, Fields of Wheat, Hills of Blood: Passages to Nationhood in Greek Macedonia, 1870-1990 (Chicago: University of Chicago Press, 1997); Charles and Barbara Jelavich, The Establishment of the Balkan National States, 1804-1920 (Seattle: University of Washington Press, 2000 [1977]); Tchavdar Marinov, 'In Defense of the Native Tongue: The Standardization of the Macedonian Language and the Bulgarian-Macedonian Linguistic Controversies', in Roumen Daskalov and Tchavdar Marinov, eds., Entangled Histories of the Balkans, Vol. I: National Ideologies and Language Policies (Leiden and Boston: Brill, 2013); Tchavdar Marinov, 'Famous Macedonia, The Land of Alexander: Macedonian Identity at the Crossroads of Greek, Bulgarian and Serbian Nationalism', in Daskalov and Marinov, Entangled Histories of the Balkans, Vol. I; Evangelos Kofos, Nationalism and Communism in Macedonia: Civil Conflict, Politics of Mutation, National Identity (New Rochelle: Astide D. Caratzas, 1993); Ivo Banac, The National Question in Yugoslavia: Origins, History, Politics (Ithaca: Cornell University Press), 1984.

30 Brown, Past in Question, 41.

31 Ibid.

32 Kofos, Nationalism, 46-7.

33 I follow the terminology used by my sources and particularly by Andrija Štampar. I likewise use the contemporary spellings for names of towns, 'Skoplje' for the modern 'Skopje', 'Bitolj' for the modern 'Bitola' and 'Peć' for the modern 'Pena'. To use the modern names would suggest a national inevitability that did not exist in the 1920s. 
with Serbs, Bulgarians, Greeks, Turks, Jews, Gypsies and Albanians. ${ }^{34}$ 'South Serbia', which encompassed both Macedonian and East Montenegrin territories, had a population of roughly 2 million in $1926 .{ }^{35}$ At the beginning of the 1920s only four Yugoslav cities had more than 50,000 inhabitants: Belgrade, Zagreb, Ljubljana and Sarajevo. ${ }^{36}$ But Skoplje, the capital of the Macedonian region, asserted a new status in the country by joining this group in the middle of the decade, with 60,000 inhabitants in 1926 and 75,000 a decade later. ${ }^{37}$

The young Yugoslavia proclaimed federative and democratic principles but essentially maintained the colonial rule Serbia had enacted when it annexed its piece of Macedonia in 1913 at the conclusion of the Balkan Wars. ${ }^{38}$ In the early 1920s the Belgrade government responded to tensions by sending colonists and military units with brutal reputations. ${ }^{39}$ Some areas, especially along the eastern border with Bulgaria, remained virtual war zones, the population pitched against a colonising government. ${ }^{40}$ The ruling government sought to expunge the Macedonian language. One strategy, removing school teachers who did not speak Serbo-Croatian, left 50 per cent of schools in Macedonia without teachers. ${ }^{41}$ A Serbian colonial elite slipped into the space the Ottomans had vacated, ensuring that national identity remained associated with class and foreign occupation. Resistance escalated into the early 1920s when the Yugoslav state failed to alter that pattern.

1924 was a pivotal year for Macedonia. In that year the Bulgarian and Yugoslav governments allied in suppressing the militant separatist Internal Macedonian Revolutionary Organisation (IMRO). ${ }^{42}$ Also in 1924 the League of Nations declared population transfers between countries interested in the territory to be complete, freeing the Balkan states to pursue nationalisation projects. ${ }^{43}$ In response IMRO became more explicitly a terrorist organisation. ${ }^{44}$ Yugoslav policy in its southern provinces grew more repressive and militaristic.

Štampar suggested a subtler approach to extending the new state's reach into the region. He argued that Macedonia 'cannot be pacified by arms but that it can be pacified by public education and public health'. ${ }^{45}$ He was convinced that public services would in fact go beyond 'pacification' and would contribute to integrating and democratising a Yugoslav state. Štampar called his health programme a tool in 'the political consolidation of Jugoslavia'. ${ }^{46} \mathrm{He}$ required his staff 'to work for Yugoslavia and not for one of the provinces and to act on democratic principles'. ${ }^{47}$ Political, or civil, values could also define nationality. Štampar's state building project deprioritised the elements that defined national identity in the nineteenth century - ethnicity, religion, language and history - in exchange for civic values.

\footnotetext{
34 Rebecca West, Black Lamb and Grey Falcon: A Journey Through Yugoslavia (London: Penguin, 2007 [1941]), 660-1. On the multi-cultural history of Macedonia, see Mark Mazower, Salonica, City of Ghosts: Christians, Muslims and Jews, 14301950 (New York: Alfred A. Knopf, 2005).

35 Mitchell, 1926 Report, 78.

36 Gunn, 1924 Report, 2.

37 Mitchell, 1926 Report, 78; West, Black Lamb, Vol. II, 14.

38 Karakasidou, Fields, 286.

39 Mitchell, 1927 Report. On the military and settlers, see Banac, National Question, 308, 320; Kofos, Nationalism, 47; Brown, Past in Question, 42. Zylberman estimates that 45,000 Serbian settlers moved to Macedonia between 1920 and 1936: Zylberman, 'Mosquitos and Komitadjis', 324.

40 Brown, Past in Question, 42.

41 Gunn, 1924 Report, 3; H. O. Eversole, 'Medical Education in Jugoslavia', 1923, 4-5, RF, 1.1/710/2/15.

42 Joseph Rothschild, East Central Europe Between the Two World Wars (Seattle: University of Washington Press, 1990), 338-44; Dimitris Livanios, The Macedonian Question: Britain and the Southern Balkans, 1939-1949 (Oxford: Oxford University Press, 2008), 27; Kofos, Nationalism, 51.

43 Karakasidou, Fields, 133; Kofos, Nationalism, 42.

44 Banac, National Question, 321-5; Brown, Past in Question, 262; Kofos, Nationalism, 51-2.

45 Gunn, 1924 Report, 10.

46 Ibid., 56.

47 Ibid., 57. On Štampar and democracy, see also Zylberman, 'Fewer Parallels', 88.
} 


\section{The Macedonian Health Project}

In 1924, the year when tensions in Macedonia reached a crisis, Andrija Štampar began his new rural health initiative within the Department of Public Health. ${ }^{48}$ In order for social medicine to function, and to build the necessary institutions for a comprehensive health service, Štampar argued that medicine had to undergo 'democratisation' and become 'socialised' ${ }^{49}$ It was in troubled Macedonia that Štampar put his rhetoric into practice.

Health itself is power. Democracy cannot exist without healthy citizens, Štampar believed. In the young Yugoslav state he consciously set about using healthcare to marshal the population toward democracy. ${ }^{50}$ In an era when the principles of democracy were bandied about as a solution to social ills, Štampar made a pragmatic commitment to these ideals. By establishing services in response to local requests to the Department of Public Health, his programme made each request into a performative act affirming the relationship between the people and the state, enacting democratic choice and providing tangible benefits in exchange for local contributions.

Public health experts from the West had trouble understanding the justification for losing efficiency in favour of democratic participation. One American visiting Yugoslavia lamented Štampar's convictions, stating that it would be much easier to implement a public health system 'in a colony or a mandate than in a democracy'. ${ }^{51}$ However, the benefits of Štampar's model were not limited to an anticipation of future democracy. In the present his approach offered a strategy for implementing reforms in a new state. As health officials learned when they tried to alter legislation both in Yugoslavia and across post-imperial Eastern Europe, the government did not necessarily have the reach to enforce laws. ${ }^{52}$ Reform required the cooperation of the people.

Štampar asserted he would have accomplished nothing without 'the goodwill of the people. He can only go as far as they will let him. ${ }^{53}$ Concerned with popular interest in the project, Štampar transformed a few villages into models to inspire neighbours with a sense of possible options. Model villages included clean water supplies and removal of stagnant water; public baths; sanitary streets, yards and homes; a sample house suitable to climatic and economic conditions; classes in 'domestic economy' and a village health centre where a nurse would oversee a small hospital, and where a doctor and a veterinarian would visit on a regular basis. ${ }^{54}$ Schools and education figured prominently in the programme. The project included teacher training with a public health dimension for young local women who would return to teach in their own districts. ${ }^{55}$ When reaching out to new villages, the project began its activity, where possible, by attaching health clinics to schools. ${ }^{56}$ Štampar considered the school clinics his most important work, believing that education empowered informed decision making and that children would 'take what they learn into their homes' ${ }^{57}$ Early in his career Štampar wrote: 'the popularisation of medicine is a powerful factor in its action. The spreading of general education should be carried out jointly with the spreading of health education. ${ }^{58}$

After the project established model villages it would expand by responding to requests for facilities and services and would increasingly depend on contributions from local communities.

\footnotetext{
48 Ibid., 236.

49 Štampar, 'Social Medicine', 53; Štampar to Gunn, 17 July 1926, RF, 1.1/710/2/11.

50 Štampar to Rajchman, 24 Dec. 1924, LNHO, R.853/12B/26249/27295X.

51 Hackett to Gunn, 25 Mar. 1925, RF, 1.1/710/2/11.

52 Hynek J. Pelc, MD, DPH, Organisation of the Public Health Services in Czechoslovakia, League of Nations Health Organisation, 1925, C.H.268, 10; Hackett to Gunn, 25 Mar. 1925, RF, 1.1/710/2/11.

53 Hackett to Gunn, 25 Mar. 1925, RF, 1.1/710/2/11.

54 Gunn, 1924 Report, 236-7; Gunn diary, 15 Feb. 1928, RF, 1.1/710/2/11.

55 Mitchell, 1926 Report, 79-80.

56 Gunn, 1926 Report, 4.

57 Ibid., 90.

58 Štampar, 'Social Medicine', 56; for more on Štampar and education, see Zylberman, 'Fewer Parallels', 84-6.
} 
Štampar considered requests as the greatest mark of his success. He wrote to Ludwik Rajchman, director of the League of Nations Health Organisation:

We receive nearly daily applications from different districts where the population is asking us to render them our help in erecting public baths, water supply, pumps and sanitary stations. I think that I am not wrong in seeing that those facts are proving the rightness of my principles that the amelioration of Public Health can be attained only through the active and most substantial support of the population. ${ }^{59}$

Štampar was likewise pleased by evidence of local readiness to contribute toward projects. As he eased away from centralisation, he placed stronger emphasis on the importance of communities themselves assembling the necessary resources. By 1926 Štampar reported that the Ministry's monetary investment often came to less that the total of local contributions. These local contributions did not necessarily come in the form of money but rather of land on which buildings would stand, of building materials such as stone and cement, of transportation for supplies and of labour. ${ }^{60}$ As villagers became familiar with Štampar's programme, they demonstrated themselves willing to travel significant distances to donate labour to projects that would benefit their communities. One of Štampar's examples was the children's 'preventorium' a hospital that would care for people at risk of tuberculosis - in the Bitolj region of Macedonia. When peasants learned that this service would be available for their children, they 'came a day's journey by foot to work'. The road to the building alone occupied no fewer than two hundred of these voluntary workers. ${ }^{61}$ Ultimately, Štampar intended the villages to take over financial aspects of the programme, assuming the expenses of maintenance and the nurse's salary, for example, 'later, when they realise the importance of the centre'. ${ }^{6}$

Through these methods Štampar worked toward 'a completely socialised public health service in which everyone gives according to his ability (taxes) and receives according to his needs' ${ }^{63}$ In general, peasants in the Macedonian region resisted being taxed by a distant government in Belgrade that they perceived as foreign, but Štampar hoped they would contribute more readily to services that they requested and from which they benefited directly. ${ }^{64} \mathrm{He}$ wanted the people to learn that government officials brought more than tax forms. ${ }^{65}$

Within a few years the Macedonia project's success was seen in new clinics and ancillary health installations spreading across the region. Štampar's own measures of success, in addition to the requests he received from villagers, were the number of first-time patient visits to clinics and the numbers who participated in inaugural festivities when a new clinic was opened. His records indicated, for example, that an estimated 140,000 people made first visits to a select sampling of the new institutions in Macedonia during their first year of operation. ${ }^{66}$ Štampar likewise felt his methods were justified by the 3,000 locals who attended the opening of the 'Home of Public Health' in Peć. ${ }^{67}$ He took these numbers to be signs of democracy at work. When he visited the Slovakian provinces of Czechoslovakia to advise on rural health he criticised their lack of democratic engagement. He noted that at a Slovakian clinic's inauguration and on similar occasions he 'saw no peasants coming out of the small houses' and that only the well-to-do attended. ${ }^{68}$

\footnotetext{
59 Štampar to Rajchman, 16 Nov. 1926, LNHO, R.991/12B/55556X/55556.

60 Mitchell to Gunn, 17 Sept. 1926, RF, 6.1/1.3/48/539; Mitchell, 1926 Report, 37-8, 60.

61 Mitchell, 1926 Report, 61-2.

${ }^{62}$ Gunn, 1924 Report, 236-7.

63 Ibid.

64 Gunn, 1924 Report, 237; Mitchell, 1927 Report, 30-1.

65 Andrija Štampar speaking in Minutes of Third Meeting, 22 Apr. 1926, Teaching of Hygiene: Proceedings of Fourth Session of Committee at Warsaw, LNHO, R.861/12B/26435/51114X.

66 Gunn to Russell (citing information from Štampar), 17 Nov. 1925, RF, 1.1/710/2/11.

67 Ibid.

68 Štampar to Alice Masaryková, 1 Mar. 1933, HDA, 831.5.
} 
Štampar's successes also emerged in details of daily life that escaped the official record. When the novelist Rebecca West toured Macedonia a decade after Štampar's project began she recorded a village's excitement over the arrival of a petty government official: finally, they had someone to whom to appeal their conflict over water rights with a neighbouring village. Notably, access to clean water was one of the fundamental components of Štampar's programme. West learned that the two villages had feuded violently for generations but now they sought government intervention. They assumed the right to submit requests to government officials and expected the government to act fairly in response. West reported that, after applying for mediation, the villagers took the opportunity to express their opinions on the country's political questions to this civil servant from Belgrade. ${ }^{69}$

Štampar's project in Macedonia won him the attention and praise of international colleagues. He was most gratified, however, by the support of the people he had wished to help. When political opponents attacked Štampar, he reported to Rajchman with pleasure that Macedonians spoke out in his favour. ${ }^{70}$

\section{Rural Health and International Development}

Štampar's project placed the Macedonian region's agrarian nature at the centre of the health programme. His methods anticipated by several years the emergence of 'peasant studies', a field concerned with both understanding and reforming agrarian society. The new discipline was an effort to address the fragile agrarian economies that threatened global food security during the Great Depression. ${ }^{71}$ The field arose in Eastern Europe and Asia, from precisely those locations where the League Health Organisation had promoted rural health projects. It would be the prototype for 'development studies' thirty years later. ${ }^{72}$ The term 'international development' is anachronistic when applied to the 1920s and 1930s but explains the particular interest in rural modernisation that the League Health Organisation pursued. Before 'peasant studies' or 'development studies' became familiar terms, rural health projects drove international collaboration between people interested in exploring alternative paths to modernisation. The League of Nations's interest in social stability and resource distribution was not a response to the Great Depression but rather a natural progression from the League Health Organisation's involvement in the post-imperial democratic state building of the 1920s.

Ludwik Rajchman was one of Štampar's interlocutors from the beginning of his project. He put Štampar in conversation with colleagues engaged in similar endeavours, through conferences, commissions and study tours sponsored by the League Health Organisation. ${ }^{73}$ In the early 1920 s Rajchman established a regional approach to collaboration, even sponsoring a 'Little Health Entente'.74 The idea mimicked the 'Little Entente' between Czechoslovakia, Romania and Yugoslavia, but with a wider membership - extending even to the First World War's defeated powers.

This network within the League Health Organisation posed a question that had been at the heart of Štampar's project: what would an agrarian version of modernisation look like, as

\footnotetext{
69 West, Black Lamb, 675-6.

70 Štampar to Rajchman, 24 Dec. 1924, LNHO, R.853/12B/26249/27295X.

71 Amrith and Clavin, 'Feeding the World', 29.

72 Ibid., 34.

73 See examples in Charles W. Pipkin, The Interchange of Public Health Personnel under the Health Organization of the League of Nations: A Story of the Creation of an International Standard of Public Health Administration (Geneva: Atar, 1928); Proceedings of 4th session of Committee at Warsaw, April 1926, LNHO, R.861/12B/26435/51114X; 'Enseignement de l'hygiène', R.861/12B/26435/49913; 'Report on its Tour of Investigation in certain European Countries in 1924', s.n. (Geneva: League of Nations, 1925) C.H.273.

74 Selskar Gunn, 'Report on Poland', 7-11 Jan. 1922, 1, RF, 6.1/1.3/47/528; Paul Weindling, 'Public Health and Political Stabilisation: The Rockefeller Foundation in Central and Eastern Europe between the Two World Wars', Minerva, 31, 3 (1993), 262.
} 
opposed to its industrial and urban counterpart? With this question in mind Štampar's project had been integrating health with contingent concerns, overlaying socio-economic development, agrarian reform and the 'popularisation' of health science. When the Ministry of Agriculture in Yugoslavia failed to cooperate to Štampar's satisfaction, he used his own medical staff to introduce modern farming techniques, such as land management or replacing wooden ploughs with metal implements. ${ }^{75}$ He also incorporated a 'Peasant University' into his School of Public Health in Zagreb. The curriculum covered agricultural science, economics and health. ${ }^{76}$ Agrarian modernisation under Štampar's direction was another element in his opposition to rising nationalism. The idea of the progressive peasant challenged right-wing portrayals of peasants as the untainted repository of national tradition and identity.

By 1927 Rajchman had begun to consider opportunities for exporting the Eastern European model of rural health and agrarian modernisation. In that year he toured South America, where he concluded 'that the enthusiastic application of American principles to European and South American conditions does require - and sometimes the need is urgent - a definite corrective'. ${ }^{77}$ The US system addressed diseases of specific concern rather than the broader socio-economic environment. $^{78}$ It also failed to incorporate insurance. ${ }^{79}$

Returning from South America Rajchman looked with interest to a conference that Štampar was organising. The occasion would be a cooperative transnational event, with participants visiting both Hungary and Yugoslavia to inaugurate an Institute of Public Health in Budapest and the School of Public Health in Zagreb. ${ }^{80}$ Štampar had begun raising funds for this School of Public Health the same year he commenced the Macedonia project. ${ }^{81}$ It was here that training in social medicine for young physicians occurred alongside classes for peasants. Rajchman argued that this conference tour would do more than contribute to shaping the agenda for the new institutes. It would systematise Eastern European rural health into an exportable form: 'the conclusions of the Conference will most probably contribute largely towards determining the programmes of the two new schools, whose activities, in their turn, will greatly influence the character of public health services in a larger part of Central, Eastern, and South-Eastern Europe as well as in Latin America'. ${ }^{2}$

The League Health Organisation continued to develop its facility for international involvement in rural health. In 1928 the Health Organisation was already considering requests to hold a major conference to address the subject. ${ }^{83}$ In 1929 Rajchman proposed hiring Štampar as the

75 Louis Adamic, The Native's Return: An American Immigrant Visits Yugoslavia and Discovers His Old Country (New York: Harper \& Brothers, 1934), 321.

76 Štampar to David H. Stevens, HDA, 831.

77 Rajchman to George Newman, 26 Aug. 1927, LNHO, R.952/12B/41197/57656X.

78 Andrew Balfour, 'New Conceptions in the Teaching of Public Health', British Medical Journal, 6 Sept. 1924, 393-7; Cueto, 'Rockefeller Foundation and Latin American Public Health', 222-43; John Farley, To Cast Out Disease: A History of the International Health Division of the Rockefeller Foundation (1913-1951) (Oxford: Oxford University Press, 2004), $203-15$.

79 Chikako Usui, 'Welfare State Development in a World System Context: Event History Analysis of First Social Insurance Legislation among 60 Countries, 1880-1960', in Thomas Janoski and Alexander M. Hicks, eds., The Comparative Political Economy of the Welfare State (Cambridge: Cambridge University Press, 1994).

80 Štampar to Rajchman, 21 Dec. 1926; Štampar to Rajchman, 19 Feb. 1927; Rajchman to Štampar, 29 Mar. 1927: LNHO, R.952/12B/41197/57656X; 'Inauguration of the School of Hygiene at Zagreb', LNHO, R.952/12B/41197/57656; 'Inauguration of Schools of Public Health at Budapest and Zagreb: Reports on the Conference', LNHO, R.861/12B/26435/62771; 'L'inauguration de l'institute d'hygiène de Budapest', LNHO, R.861/12B/26435/62548.

81 On the Zagreb School and Rockefeller Foundation, see Željko Dugac, 'New Public Health for a New State: Interwar Public Health in the Kingdom of Serbs, Croats, and Slovenes (Kingdom of Yugoslavia) and the Rockefeller Foundation', in Borowy and Gruner, Facing Illness, 277-304.

82 Rajchman to Newman, 26 Aug. 1927, LNHO, R.952/12B/41197/57656X.

83 Annual Report to the Health Organisation for 928, 18 Apr. 1929, A.81929III/C.H.788, 5, 50; Cited in Iris Borowy, 'International Social Medicine between the Wars: Positioning a Volatile Concept', Hygiea Internationalis, 6, 2 (2007), 117-21; Borowy, Coming to Terms, 325-43, 358-60. 
League's rural health expert. He formalised the position after Štampar's government turned hostile to him in $1931 .^{84}$

While Rajchman first considered the possibility of expanding these programmes toward South America, his opportunity came two years later from another direction. A civil war in China had recently ended and the victorious government was eager to secure governing authority over its territory. The ruling party particularly feared that dissatisfied peasants, who made up 80 per cent of the population, would turn towards the communists. ${ }^{85}$ As in Macedonia, healthcare might be a basis for political consolidation. In 1929 the Chinese government invited the League Health Organisation to collaborate in building China's national health service. ${ }^{86}$

Rajchman saw in this collaboration an opportunity to advance the methods he had encouraged in Eastern Europe. In China, he believed, a new practice of modern medicine might avoid the Western separation of preventative and curative practice, instead uniting individual health with social medicine. ${ }^{87}$ He thought the moment was auspicious for China to lead in charting a new path: 'two powerful appeals - the American and the Soviet - have been made to the mind of Young China since the war. Enthusiasm for America is noticeably cooling down; that for the Soviets, after the ruthless repression of various risings and the contact with the Russians, is now in a reflective mood. ${ }^{88}$ Eastern European health reformers, Rajchman believed, had the ideal experience to offer guidance to their Chinese colleagues. He happily reported to the League's secretary-general that Chinese officials already associated the new Eastern European states in particular with the League of Nations, to which they had appealed for aid: 'for New China, Europe, and the newer European States - is closely identified with the League'. ${ }^{89}$

Following his first visit to China Rajchman turned to the Yugoslav rural public health programme for personnel. He selected Berislav Borčić (1891-1977), director of the School of Public Health in Zagreb and one of Štampar's closest collaborators, to run the League Health Organisation programme in China. ${ }^{90}$ Štampar would himself make extended visits to China, traveling repeatedly into the country's interior. Eastern European and Chinese reformers should work together, Stampar told a Chinese colleague, because the world was not divided into East and West, but into industrial and agrarian societies. ${ }^{91}$

Although the League Health Organisation was invited to China by the government, it demonstrated the same scepticism of state politics that Śtampar had shown in Yugoslavia. Its officials adhered to their own values and made connections directly with provincial colleagues. Štampar again admonished his team to engage at a local level. ${ }^{92}$ Democratic empowerment also figured in the planning. Borčić, for example, emphasised that each village's 'health assistant' was

\footnotetext{
${ }^{84}$ Andrija Štampar's Personnel File, LNHO, S.886/3355; Gunn's diary, 18 Feb. 1929; 11 Mar. 1930; 25 Mar. 1931; Gunn to Max Mason, 22 Apr. 1931; Russell to Štampar, 2 July 1931: RF, 1.1/710/2/11.

85 C. G. M. Klein Goldewijk and J. J. Battjes, A Hundred Year (1890-1990) Database for Integrated Environmental Assessments (Bilthoven: Rijksinstituut voor Volksgezondheid en Mileuhygiëne, 1997); 'China in Statistics', Chinese Social and Political Science Review, xiv, 4, s.n. (1930), 445-70; on expanding programmes, see 'Health Organisation. Public Health Activities in China from 1929-1935. Statement made by Dr. Borcic before the Health Committee on October $9^{\text {th }}$, 1935', 23 Nov. 1935, 17, 19, C.H.1195, LNHO R.5711/50/6501/21438. Joseph Avenol to Borčić, 6 Sept. 1933, LNHO, R.6059/8A/940/3608; Andrija Štampar, 'Final Remarks on North West Health Programme', Mar. 1936, 1, LNHO, R.5710/ $50 / 6501 / 20156$.

${ }^{86}$ Telegram from C. T. Wang to Drummond, 14 Sept. 1929, reproduced in 'Survey of Health Conditions in Certain Districts of China', 1929, LNHO, R.5905/8A/10595/10595; see also 'Circular Letter from the Medical Director to the Members of the Health Committee', 25 Sept. 1929, LNHO, R.5905/8A/10595/10595.

${ }^{87}$ Memo from Rajchman to Secretary General Drummond, 5 Feb. 1930, 11, LNHO, R.5906/8A/10595/18022; 'Proposals of the National Government of the Republic of China for Collaboration with the League of Nations on Health Matters', C.118.M.38, 1930, 28, LNHO, R.5906/8A/10595/18022.

88 Rajchman memo to Drummond, 5 Feb. 1930, 17.

89 Ibid.

90 Rajchman to Avenol, Treasurer, 8 Apr. 1931, LON S.725/436; Zagreb School of Public Health, RF 6.1/1.1/30/349.

91 Štampar to Fu-Liang, 28 Sept. 1935, HDA, 831.3.
} 
to be 'chosen locally'. ${ }^{93}$ When there was a conflict between local and state interests, the League officials often ignored the latter and used their organisation to support local efforts. ${ }^{94}$ Rajchman and his Yugoslav rural health experts eventually would even break with their official hosts to favour Chinese advocates for agrarian over industrial modernisation. ${ }^{95}$

This cooperation was remote from the internationalism planned at the Paris Conference only a decade before Rajchman brought the Health Organisation to China. Collaboration around rural health led to an international organisation willing to intervene in domestic social concerns. In 1931 the Japanese invasion of Chinese Manchuria discredited the League of Nations's security mandate, its ability to preserve peace. Following this failure Rajchman would help to redefine the League by supporting a broader development programme in China. ${ }^{96}$ As the 1930s progressed internationalists would begin to believe that social medicine, infrastructure, modern agriculture and investment at the local level might be the answer to the rising tides of nationalism and battling ideologies.

\section{Conclusion}

A remote periphery of Yugoslavia was one point of origin for the internationalism of the 1930s. In the immediate future that form of internationalism proved no more capable of defeating threats than the rural health project in Yugoslavia proved capable of erasing nationalism. Later, when the internationalists pulled themselves back together after the Second World War, the legacy of the earlier rural health projects re-emerged. Their focus on local needs and on human wellbeing within social communities contributed to defining a new focus on human security, development and universal rights.

Andrija Štampar was foremost a pragmatist. Faced with the premise that a democratic state should serve its citizens equally, he set about imagining and establishing the institutions that he believed would achieve this objective. But nation states inherently limited equitable distribution of healthcare to their own citizens. And, as Štampar learned from the political culture of Yugoslavia, even relatively sympathetic governments might change direction and citizens might lose rights. So, to achieve his objective, the institutions dedicated to extending access to healthcare needed to exist beyond the state. Internationalism would have to develop the ability to preserve human wellbeing. Fortunately for Štampar he was not the only public health reformer to have this thought. Collectively the reformers within the League Health Organisation tended to conclude that states were the optimal organisational unit for establishing health services but that the state was not ultimately necessary. State builders quickly became internationalists in the late 1920s and 1930s.

Meanwhile, the rising right-wing nationalism that encouraged Štampar and his colleagues to depend increasingly on internationalism also elevated a particular strand of social medicine: eugenics. The horrific extremes that resulted from eugenicist and racist programmes discredited

\footnotetext{
92 Štampar, Dnevnik, 238-9, extended CD edition 573-4; 'Health Organisation. Public Health Activities in China from 1929-1935. Statement made by Dr. Borcic before the Health Committee on October $9^{\text {th }}, 1935$ ', 23 Nov. 1935, 11, 16-17, C.H.1195, LNHO, R.5711/50/6501/21438.

93 Borčić, 23 Nov. 1935, 17.

94 Report by Andrija Štampar, 1934, LNHO, R.5721/50/7263/12695; 'Health Organisation: Report by Dr. A. Štampar on his missions to China', 15 Oct. 1936, 18, 20, C.H.1220, LNHO, R.5710/50/6501/20156; $22^{\text {nd }}$ Session of the Health Committee: Collaboration with the Government of China in health matters. Impressions of the Activities of the Health Institutions in the North-West Provinces of China with Recommendations for the Future (Presented to the National Health Administration, Nanking) by Dr. A. Stampar, May 1935, LNHO, R.5710/50/6501/20156.

95 Margherita Zanasi, Saving the Nation: Economic Modernity in Republican China (Chicago: University of Chicago Press, 2006), 57-8 ; Marta Balińska, For the Good of Humanity: Ludwik Rajchman Medical Statesman (Budapest: Central European University Press, 1995), 96-7; Štampar, Dnevnik, 253; Štampar to Fu-Liang, 28 Sept. 1935, HDA, 831.3.

96 Arthur Salter, Memoirs of a Public Servant (London: Faber and Faber, 1961), 216-27; Štampar, Dnevnik, 238-9; Borčić to Štampar, 15 June 1931, HDA, 831.1; Balkińska, Good of Humanity, 87.
} 
this branch of science, while competing theories of social medicine such as Štampar's were obscured by this dark history.

Social medicine in the interwar years had, however, given rise to alternative landscapes of thought and activity. For Štampar 'social' meant the property of the people as much as it meant an appreciation for socio-economic determinants of health or the importance of understanding the individual's role in the community. While focusing on health, his programme proceeded on the principle that empowering people within a democracy teaches democratic values. Individual health and participatory democracy appeared to be the ultimate virtuous cycle of a strong civil society.

Štampar's concern with establishing the institutions to ensure equal access to healthcare, and thereby to preserve democracy and peace, sheds light on the experiences and aspirations of a generation of public health experts who transformed internationalism through the League Health Organisation. The idea of healthcare as a right was axiomatic to Štampar, since democratic society would crumble without it. Optimistically, he continued his project within the League Health Organisation even as the democratic order decayed. There, he and his colleagues built international institutions to protect the most basic requirements for physical thriving and human wellbeing. 